\title{
Making Geographical Connections - Via Nova Scotia, Canada
}

\author{
Richard Kotter* \\ Northumbria University at Newcastle upon Tyne, UK \\ *Corresponding Author: Richard Kotter, Northumbria University at Newcastle upon Tyne, UK
}

Geographers explore geographical connections in their imagination and through research as well as citizens across time, space, with an interest in flows in particular, at different scales - here through the lenses of economic, political and historical geography. I try and offer an example of weaving together different geographical connections not ordinarily done so prominently in regional geography approaches.

In August 2015, I spend a few weeks in one of eastern Canada's Maritime Provinces on the Atlantic [1][2], not quite geared up to do a re-take of Billy Connolly's: Journey to the Edge of the World from Halifax, Nova Scotia on the Canadian Atlantic through the notorious Northwest Passage to Vancouver Island on the Canadian Pacific coast, screened by ITV in 2008), so staying put in Nova Scotia itself. On the plane approaching Halifax, a Canadian businessman informed us that this time we should make it since the wind was not against us - unlike at times when the plane approaching from the west cannot make it there, having to return to Ottawa or Montreal.

Nova Scotia is one of the Maritime provinces, stretching 500 kilometres from northeast to southwest, with a shoreline of over 6,000 kilometres, with no point further from the sea than 70 kilometres [3]. Fittingly, I had heard of the world-famous Bedford Institute of Oceanography in Dartmouth, NS - but not much else, other than its capital Halifax and some of the universities there. It has been stated that, for centuries, Nova Scotia's interests and contacts lay across the sea with Europe, not with the rest of Canada [3] [4].

I knew that Halifax was a major port - gateway to the Atlantic - for the British Empire [5], was a citadel town for the British colonial administration of the part of Canada the British (colonists) controlled in competition with the French. The colonial wars in north eastern America from 1688 until 1760 set France, her colonists in New France and Acadia, and her aboriginal First Nations allies against the British Empire, her colonists, militias, and aboriginal allies. One of the most frequently contested areas during these conflicts was the French colony of Acadia and, after its capture by Great Britain in 1710, the new British colony of Nova Scotia [6]. Acadia was the launch pad for frequent French and First Nations raids into Maine and New England. The British tried to stop these attacks by capturing Port-Royal, the capital of French Acadia, and subduing or winning the favour of the First Nations tribes. With the support of their New England militia, the British captured and held PortRoyal beginning in 1710, renaming the place Annapolis Royal, though British control over the remainder of old Acadia proved elusive for a time as the French and First Nations struck repeatedly at Annapolis and the British fishing settlement at Canso, NS. Beginning in 1755, however, Great Britain mustered a significant force that not only drove the French military from Nova Scotia but was used to expel the remaining 8,000 majority French Acadian population from the British colony as suspected unreliable, in a scheme of ethnic cleansing with significant losses of life [7].

Referred to as the "Far Reaches of Empire", the war in Nova Scotia (1710-1760) serves Grenier [8] as a case study, though he also documents how a new form of irregular warfare took shape in the New World, on the fringe of Empire. Acquired by Britain after Queen Anne's War, the province was occupied both by French-speaking Acadians and several Native American tribes or Nova Scotian Indian or Aboriginal peoples, with the Mi'kmaq (or Micmac, called Souriquois by the French) being the founding people of Nova Scotia and remaining the predominant Aboriginal group within the province, in some reserves as well as outside. When the Mi'kmaq first encountered Europeans in the 16th and 17th centuries, their territory stretched from the southern portions of the Gaspé Peninsula 
eastward to most of modern-day New Brunswick, and all of Nova Scotia and Prince Edward Island [9].

Within half a century this population was replaced by English-speaking settlers, mostly from the Massachusetts colony, the original settlers displaced by war and governmental policies, with complex negotiations and conflicts between the island's diverse Acadian and Native American population, their English overseers, and the encroaching "Yankees" from the colony of Massachusetts [10].

One such person was Moses Perry 1714-1801, described as a Founding Father of Yarmouth, NS [11], who in 1761 left Massachusetts in a tiny boat with his family and some friends, sailing for 8 days before landing near the present day site of Yarmouth, Nova Scotia, with descendants the Perry family still local nowadays. Kearns and Peters [12] discuss artistic interventions to try and redress the marginalisation of Mi'kmaq presence in the public and heritage spaces of Nova Scotia, when seen in contrast for instance to that afforded Sir Richard Cornwallis, the first British governor, who was their historic persecutor in law and practice.

In July 2015 the Queen Mary 2, the Cunard Line's flagship ocean liner, docked at Halifax, recreating the company's first transatlantic crossing, made by the Britannia 175 years ago. Samuel Cunard was born in Halifax in 1787, working for his father in the timber and coal business before turning towards the sea. In 1840, Cunard's Britannia established the first year-round scheduled Atlantic Ocean steamship service, running from Halifax to Liverpool. Cunard expanded the company into a shipping giant, envisioning "an ocean railway," proving people could travel quickly and on schedule [13].

It is worth remembering in World War I Centenaries that Nova Scotia has played a part through the Canadian Expeditionary Force, fighting together for the first time - including the 25th Battalion (Nova Scotia Regiment) [14] [15] - at Vimy Ridge in northern France in 1917, and has played a more significant logistical supply role in WWII, to link with Liverpool (in the United Kingdom) as part of the Allied North Atlantic convoys from September 1939 outbound [16], as well as the evacuation of British securities lodged with the Royal Treasury after 1940 Canada and New York via Halifax NS to safeguard it and also to help pay for American logistical war supply.

A major maritime disaster during World War I, which destroyed significant parts of Halifax (notably the Richmond district) on $6^{\text {th }}$ December 1917, called "The Halifax Explosion", occurred when the unladen Norwegian vessel SS Imo (chartered by the Commission for Relief in Belgium to pick up a cargo of relief supplies in New York), collided with French cargo laden with high explosives ship SS Mont-Blanc Mont-Blanc (under orders from the French government to carry her cargo of high explosives from New York via Halifax to Bordeaux, France) in The Narrows, a strait connecting the upper Halifax Harbour to the Bedford Basin. Approximately 2,000 people were killed by the blast, debris, fires or collapsed buildings, and an estimated 9,000 others were injured. The blast was the largest human-made explosion before the development of nuclear weapons, releasing releasing the equivalent energy of roughly 2.9 kilotons of TNT, and nearly all structures within an 800-metre (halfmile) radius, were obliterated. [17] [18] [19].

In a significant work in critical history Remes [20] draws on the histories of the Salem Fire of 1914 and the Halifax Explosion of 1917 in the United States-Canada borderlands to explore the institutions - both formal and informal - that ordinary people relied upon in times of crisis. A century prior, governments - buoyed by Progressive Era-beliefs - began to assume greater responsibility for protecting and rescuing citizens. Yet the aftermath of these two disasters arguably saw working class survivors instead turn to friends, neighbours, co-workers, and family members for succour and aid. Meanwhile, as official and unofficial responses demonstrated, meanwhile, how the United States and Canada were linked by experts, workers, and money. Remes explores patterns and traditions of selfhelp, informal order, and solidarity and details how people adapted these traditions when necessary. Yet he argues that these methods - though often quick and effective - remained illegible to reformers. Furthermore, soldiers, social workers, and reformers wielding extraordinary emergency powers challenged these grass-roots practices to impose progressive "solutions" on what they (arguably wrongly) imagined to be a fractured social landscape.

For the souls lost from The Titanic in 1912 which went down on her maiden voyage from Southampton, Halifax became "the undertaker" with all the dead bodies which could recovered (over 200) buried there (whilst the survivors went to New York) [21] [22] [23]. 
Both incoming (through Pier 21 at Halifax, which eventually became the Canadian national immigration museum, though arguably with an inbuilt selectivity in representation [24]) and outgoing, Nova Scotia has the most intriguing and complex migration stories which have not only shaped Canada, but also Louisiana - giving birth to America's Cajun culture (the term "Cajun" being a derivation of Acadian, the French-speaking inhabitants of Nova Scotia which were under severe duress by the British-speaking colonialists) - and Sierra Leone, due to the emigration of the Black Loyalists settler community disheartened with life in Nova Scotia (as can be still explored in Shelburne, NS in the Black Loyalist Heritage Centre) - in major part due to the lack of support in situ from the British government they had fought for in the American Revolutionary War [25] [26] were driven out or relocated themselves. 1,196 Black Loyalists accepted a British offer to relocate to Sierra Leone, West Africa in January 1792, departing from Halifax in a fleet of 15 vessels. Sixty-seven people died during the voyage. The rest landed at Freetown on 28 February and 9 March [27].

Also dramatic is the expulsion of the Acadians (1755-1764) during the French (New France) and Indian War (the North American theatre of the Seven Years War between Britain and France) referred to earlier [6] [7] [8], also known as the Great Upheaval, the Great Expulsion, the Great Deportation and Le Grand Dérangement, by the British of the Acadian people from the present day Canadian Maritime provinces of Nova Scotia, New Brunswick, Prince Edward Islands, including with violence and numerous civilian deaths.

The British first deported Acadians to the then thirteen British colonies on the east coast of North America, and after 1758 transported additional Acadians to Britain (provided they swore allegiance to the British Crown) and France. In all, of the 14,100 Acadians in the region, approximately 11,500 Acadians were deported [28].

A census of 1764 (from which Stephen White calculated the published number in 1777) indicates that 2,600 Acadians remained in the colony, presumably having eluded capture [29].

In 1847, American poet Henry Wadsworth Longfellow published a long, narrative poem about the expulsion of the Acadians called "Evangeline". The song "Acadian Driftwood", recorded in 1975 by The Band, portrays the Great Upheaval and the displacement of the Acadian people. Antoine Maillet also published a novel in 1979, called "Pélagie-la-Charette", about the aftermath of the Great Upheaval. Grand-Pré Park in Nova Scotia is a National Historic Site of Canada, and preserved as a living monument to the expulsion. It contains a memorial church and a statue of Evangeline, the subject of Longfellow's poem. The song "1755" was composed by American Cajun fiddler and singer Dewey Balfa and performed on his 1987 album "Souvenirs", and later covered also covered by Steve Riley and the Mamou Playboys on their 1994 album.

In December 2003, British Governor General Adiencce Clarkson, representing Queen Elizabeth II (Canada's head of state), acknowledged the expulsion but did not apologize for it. She designated July 28 as "A Day of Commemoration of the Great Upheaval [30].

A trace of French-connected Acadia in language and culture remains, with recent place-promotion as well as as cultural politics driven efforts of a revival of the vestiges in some parts of Nova Scotia can be observed too over the last decade or so [31].

One of the greatest early migrations of Scots to North America is covered by Campey [32]. The arrival of the Hector in 1773, with nearly 200 Scottish passengers, sparked a huge influx of Scots to Nova Scotia and Cape Breton. Thousands of Scots, mainly from the Highlands and Islands, streamed into the province during the late 1700s and the first half of the nineteenth century [33] Robinson [34] covers the story of the migration of preacher Norman McLeod and over 800 highlanders from Scotland to Nova Scotia and then, 30 years later, to New Zealand.

Nova Scotia, and Halifax as its centre, of course also received quite significant Irish immigration, almost from the beginning of the time the town was founded by the British; in, 1760, they numbered ca. 1,000, one third of the population, living in the Irishtown area, largely ignored by the government due to their Catholic religion. Ulstermen and Scots-Irish were attracted - as Protestants - via Irish land speculators such as Alexander McNutt (from Londonderry, but living in Boston at the time) to settle then now vacant French Acadian farms, in the Bay of Fundy. In 1764, all told, there were 2,000 Irish in Nova Scotia (which then included New Brunswick also), with about 1,000 in Halifax, of them 
about 600 Catholic. Many more came after the disastrous Potato crop failure with land clearances following suit, with some lost in shipwrecks such as the bark Astrea off Louisburg, NS in 1834 [35].

Initiative such as, for example, the Black Cultural Centre for Nova Scotia established in 1983 to Protect, Preserve and Promote the history and culture of Black African Nova Scotians, sited in the hinterland of Dartmouth, are impressive and deserve support. The Centre is a museum and cultural gathering place where the rich history of Nova Scotians of African Descent can be discovered and explored. This includes the story of Canada's No 2 Construction Battalion. As Canada entered the Great War, there was no definitive national policy on enrolment of African Canadians in the Canadian Army, and the decision whether or not to enrol blacks was left to unit commanding officers. Most blacks were turned away, with the exception of the $106^{\text {th }}$ Battalion, Nova Scotia Rifles, in Truro. However, more were turned away than were enrolled because of the belief that "it was a white man's war" and the fear of an integrated army. Under pressure from both politicians and the black community, with manpower starting to become a problem due to losses resulting from death and causalities, Canada's Militia Council in April 1916 authorized the formation of a black construction battalion, commanded by white officers and with a few white senior NCOs of previous military experience, headquartered in Pictou, Nova Scotia. The decision to form a construction battalion was based on the fact that Canada's black population could not sustain an infantry battalion in action. The exception to the white officer's policy was the unit padre, Honorary Captain, the Reverend, William A. White who was one of the few black officers in the Canadian Army in the First World War [36] [37].

One of the major tourism offerings of in Nova Scotia today is the historic harbour town of Lunenburg on its southern shore. In Canada, Lunenburg is famous the famous sailing ship, the Bluenose fishing schooner, completed in 1921, which won the "Fisherman's Cup" fishing boat sailing regatta held traditionally between the town of Lunenburg (Nova Scotia) and Gloucester (Massachusetts, USA) 17 years in a row. In 1938, when the great fishing schooners were replaced by the motorised trawlers, the ship was sold and with the beginning of World War Two the masts were capped and a motor build in, and subsequently the Bluenose was used as a freight vessel between Canada and the Caribbean, sinking off Haiti in 1946. In 1963, a replica (the Bluenose II) was build, which is a major attraction now.

A deeper international migration story of Lunenburg is reflected by its UNESCO World Heritage Centre, encompassing its old town. This includes peculiar foreign European protestants' house architecture( with massive and sometimes elaborate wooden houses, many with an architectural overhang - the characteristic 'Lunenburg bump' - above the main entrance), but also the best surviving example of a planned British colonial settlement in North America preceding it. Established in 1753, it has retained its original layout and overall appearance, based on a rectangular grid pattern drawn up in Britain at the time. http://whc.unesco.org/en/list/741

According to the Nova Scotia Archives [38], Halifax was founded in 1749 as Nova Scotia's capital, but within a year desertion and disease had drastically thinned the initial population of the predominantly English community. However, the early town inhabitants included some industrious Germans and Swiss whose dependability impressed the local officials. 'They persuaded the British imperial government in London to recruit replacement settlers like them, from various German states and principalities - and some Swiss and French ones also who spoke French - often along the Rhine River in western Europe. The British promised these new immigrants free land, a year's supply of food, tools and implements necessary to till the soil, and some building materials. If they could not pay their passage, they were still welcome to come, but after their arrival would be required to labour on public works such as forts and roads until they redeemed their debt. As a result, some 2,700 new settlers arrived in Halifax between 1750-52, coming mostly from the Palatinate, Württemberg, Baden, Hesse-Darmstadt, Switzerland and Montbéliard - a small principality near the French border with Switzerland. The new arrivals spoke German, except those from Switzerland and Montbéliard, who spoke French. Since religion and political allegiance were often linked in those days, the immigrants were almost all Protestants, and during their early years in Nova Scotia were known collectively as 'the Foreign Protestants' to distinguish them from the Acadian French.

In 1753, about half of them were taken from Halifax by boat to settle a new planned community called Lunenburg, on Nova Scotia's South Shore. There was a period of adjustment as land was 
cleared, homes were built, crops were planted, and the settlers learned to fish as well as farm, but within a generation they were self-sufficient. To this day, the descendants of these early Foreign Protestants form the predominant cultural group in Lunenburg County. With surnames to reflect this though those are regarded as solid old Nova Scotia surnames now. Before long, some of the Lunenburg settlers pulled up stakes and moved elsewhere in the province. The Foreign Protestants of the 1750s were not the only German-speaking immigrants to Nova Scotia in the early days. At the end of the American Revolution, several dozen Hessian soldiers recruited as auxiliary troops for service in North America remained behind to settle and establish families in the province, mostly near Annapolis. Also, some of the American Loyalists ('Tories') coming to Nova Scotia as political refugees after 1783 were also of German origin. Other German-speaking immigrants were occasionally added to the population over the years, some as veterans of various wars in the 18th and early 19 th centuries, others drawn here by a gold rush in the 1860 s.'

To return to Halifax, on the shores of the Bedford Basin, that is on the northern edge of peninsular Halifax, lies Africville. For over 150 years, Africville was home to the hundreds of individuals and families who settled there, some of whom could trace their roots in Nova Scotia back to the late 1700s. According to the Africville museum [39], 'Africville was a vibrant, self-sustaining community that thrived despite the harshest opposition. The majority of those who lived in Africville were landowners; in fact, the first registered deed dates back to 1848.' Furthermore, according to the Africville Museum , 'Despite the prevalent perception of Africville as a "slum" populated by "squatters", residents paid taxes, had meaningful employment, tended their gardens, raised their children and took pride in their homes, however modest. Those who lived there recall a community of brightly painted houses where neighbour helped neighbour. Africville, with its community-built and operated school (circa 1883), a church (circa 1849, and later rebuilt in 1916) - the community's spiritual and social centre - and a post office, thrived in spite of nearly insurmountable challenges. Despite paying municipal taxes and years of petition, residents lived without the services taken for granted by others, including water, sewage, paved roads, police, ambulance and fire truck service. Industrialization soon began to encroach on the community as railway after railway started running through the area (circa 1854). Facilities unwanted by other communities such as a prison, a slaughterhouse, and an infectious disease hospital were located in and around Africville. While other parts of the city received investments to modernize and renew, the isolated community of Africville was left to ruin. In 1958, Africville earned the dubious distinction of being officially labeled a "slum", when the city moved the town dump (circa 1955) to an area just a stone's throw to the church and people's homes. As early as 1945, discussions were being held regarding the removal of Africville. In 1948 funds were approved for sewer services but never installed. Residents relied upon local springs that were long since contaminated by the railway and surrounding industrial waste. From the prison to the railways, each new fixture meant the expropriation of hard-earned land from those who were the rightful owners. The final result of over 150 years of unequal opportunity arrived in 1962, when Halifax City Council used the threat of expropriation to negotiate the purchase of their land. Between 1964 and 1970, residents were removed with many families being placed in public housing projects. Homes were demolished and the church bulldozed in the middle of the night. The means of displacement served as a metaphor for how the community of Africville was regarded: the city moved some of the residents' belongings in municipal dump trucks [40].

According to the Africville Museum, 'in 1969 the people of Africville began seeking redress with the formation of the Africville Action Committee to reunite the people. In 1983, the Africville Genealogy Society was formed by three women (Deborah Dixon, Linda Mantley and Brenda Steed-Ross)and in 1985, the society began to seek recompense from the city of Halifax for the destruction of the Africville community. The African Genealogy Society (AGS) and the following year, they planned another community gathering known as the "Africville Reunion", which still remains an annual event in the park each July. This was the beginning of a new chapter in the history of Africville. Community members worked with writers, film makers, and artists to share their story with a larger audience. An exhibit telling the story of Africville was created, and toured across Canada. On behalf of the people who had been moved from Africville, the AGS initiated legal action for recompense for their loss. They attained a United Nations decision supporting their claim. For more than 25 years, the people of Africville worked to achieve a settlement. In 2010, after a long fight, a settlement was finally reached with the city which included 2.5 acres of land to serve for the reconstruction of the church, $\$ 3$ million toward the construction costs and a formal public apology by Mayor Peter Kelly. In an emotional and 
uplifting ceremony that drew hundreds of people, the replica of Seaview Church was officially opened in the fall of 2011. The ribbon was cut by Bertha Mantley, who at 91 is one of the oldest surviving resident. With the official apology and the construction of the Church, they began yet another chapter in the history of Africville. The Museum is the first stage of the Africville Project, which will later include an Interpretive Centre.'

Some of my abiding impressions from 3 weeks in Nova Scotia are of being constantly surprised to encounter complex stories of movement and connections being woven and - at time very violently and enforced - unwoven, only to create new ones. For me, this is one of the key areas to explore as human geographers, because it makes the geographical imagination lively, accessible - and human.

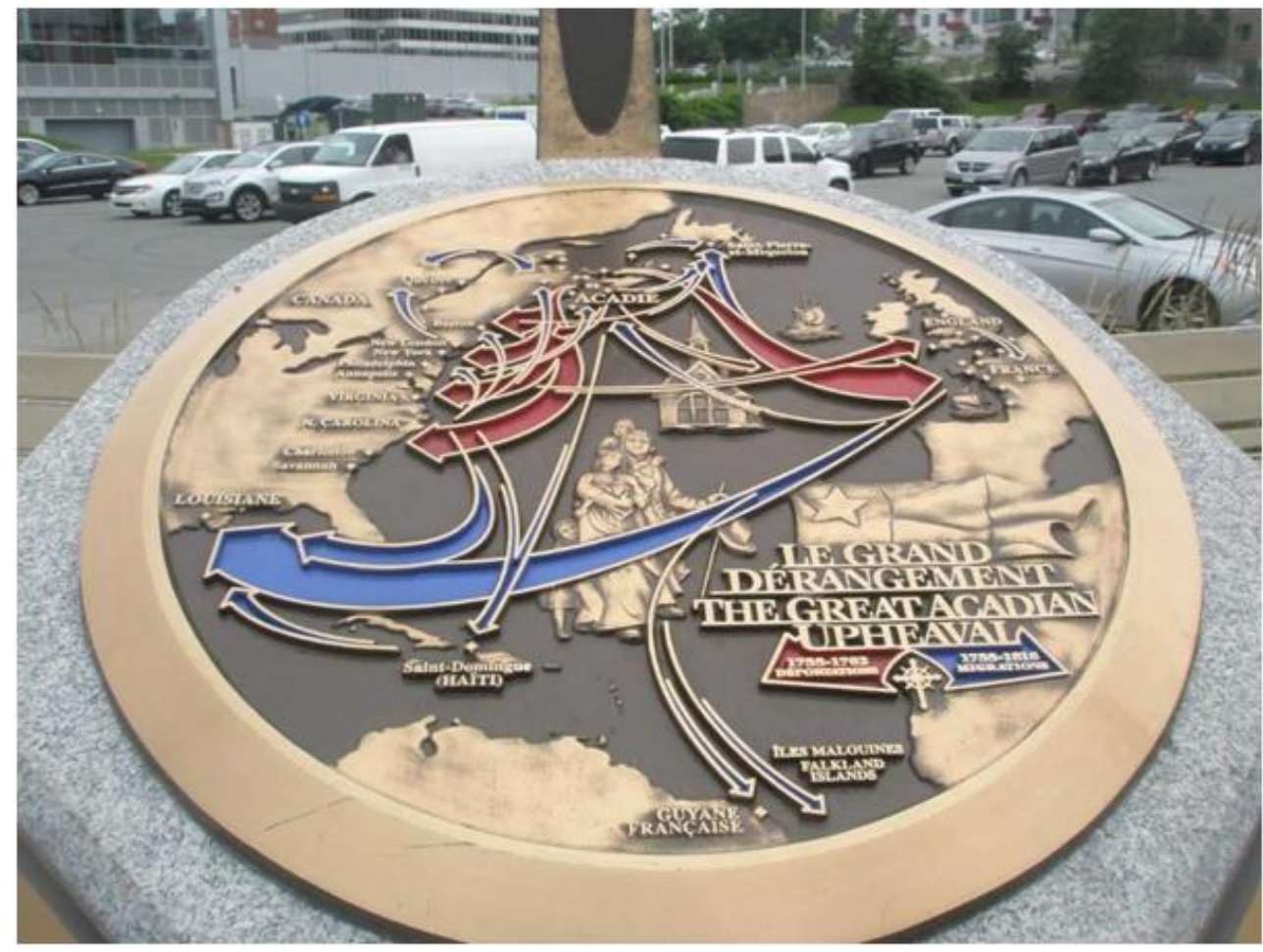

The Great Derangement / The Great Acadian Upheaval, monument / memorial in Halifax, Nova Scotia, Canada.



The Great Derangement / The Great Acadian Upheaval, monument / memorial in Halifax, Nova Scotia, Canada. 


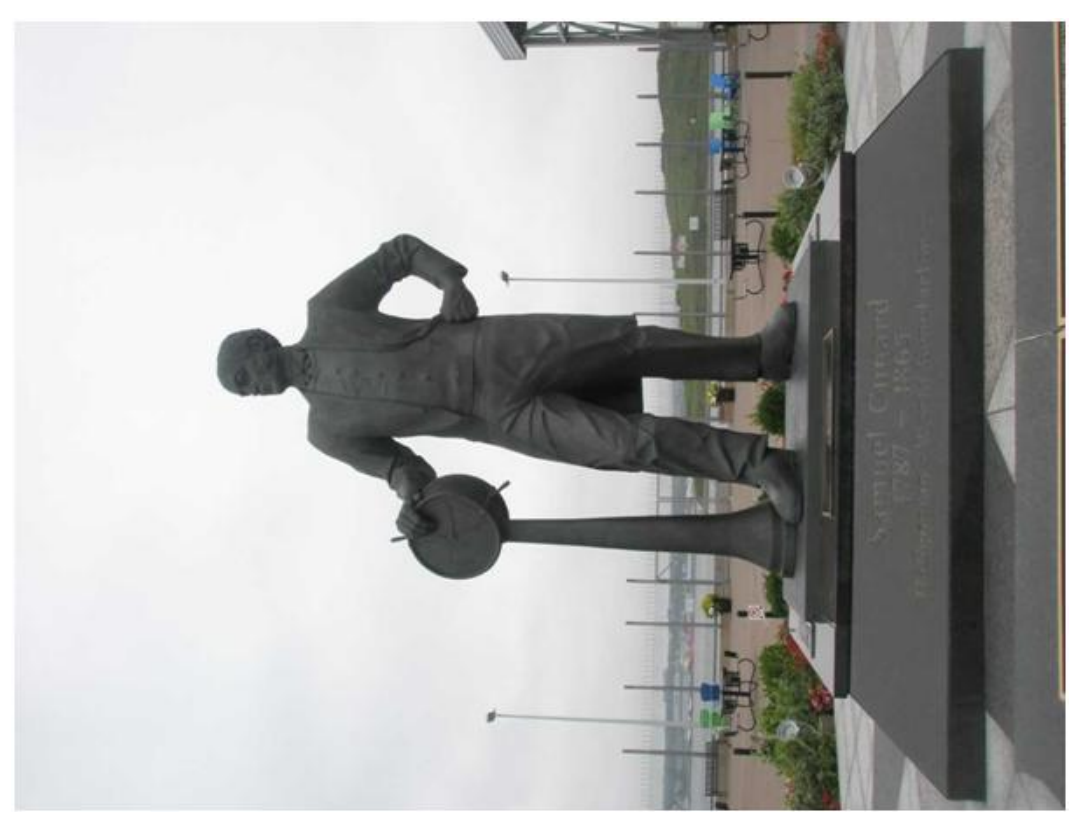

Samuel Cunard statue, Halifax, Nova Scotia, Canada's

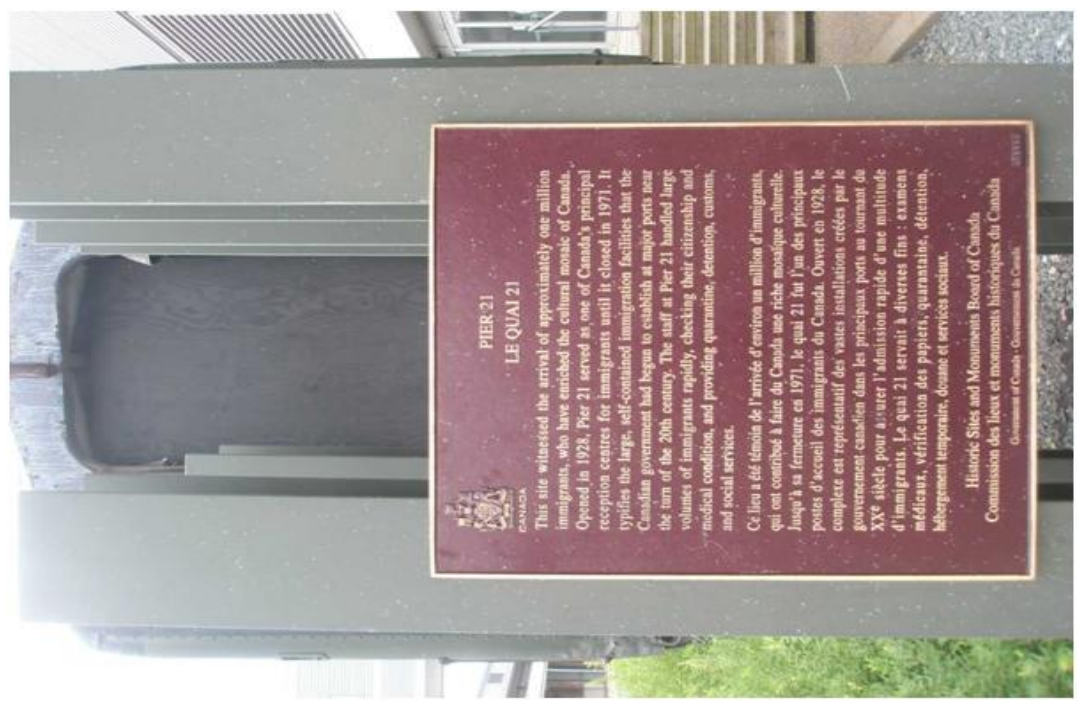

Pier 21, Halifax, Nova Scotia

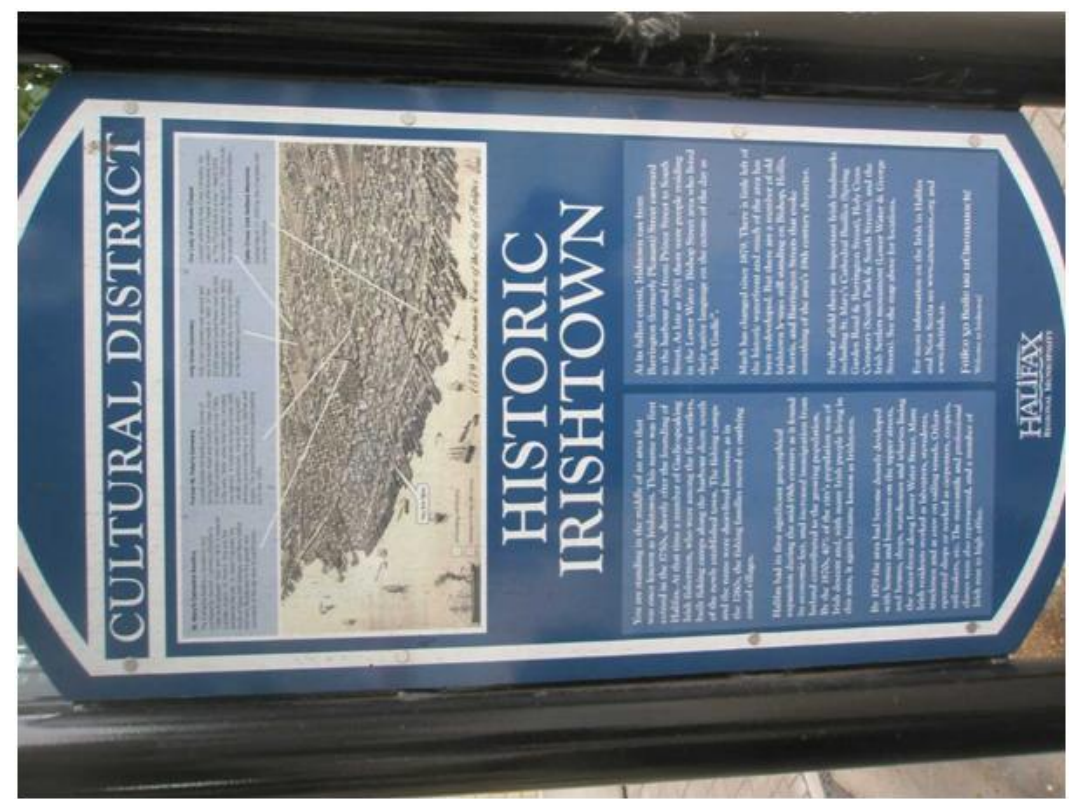

Halifax Irishtown interpretation plaque, Halifax, Nova Scotia, Canada 


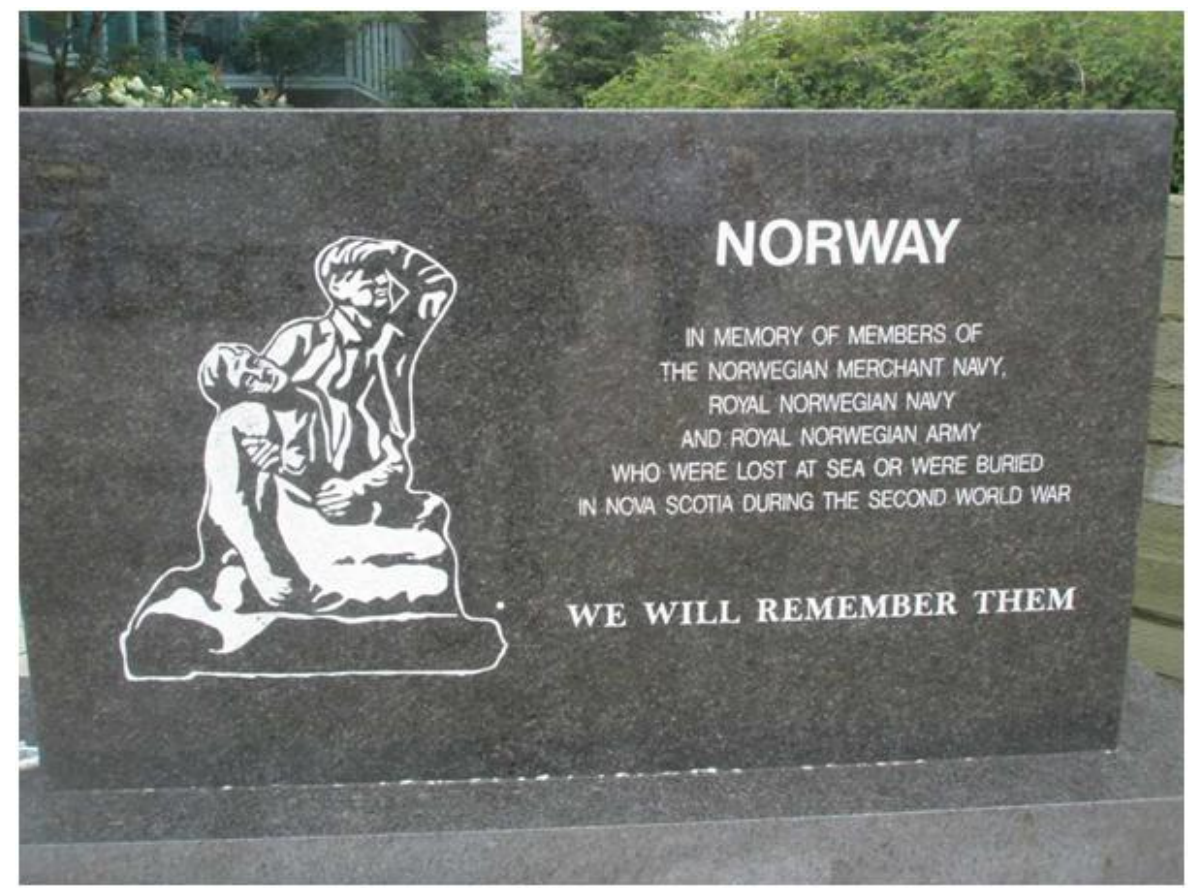

Norwegian Merchant Navy WWII Memorial, Chester, Nova Scotia, Canada

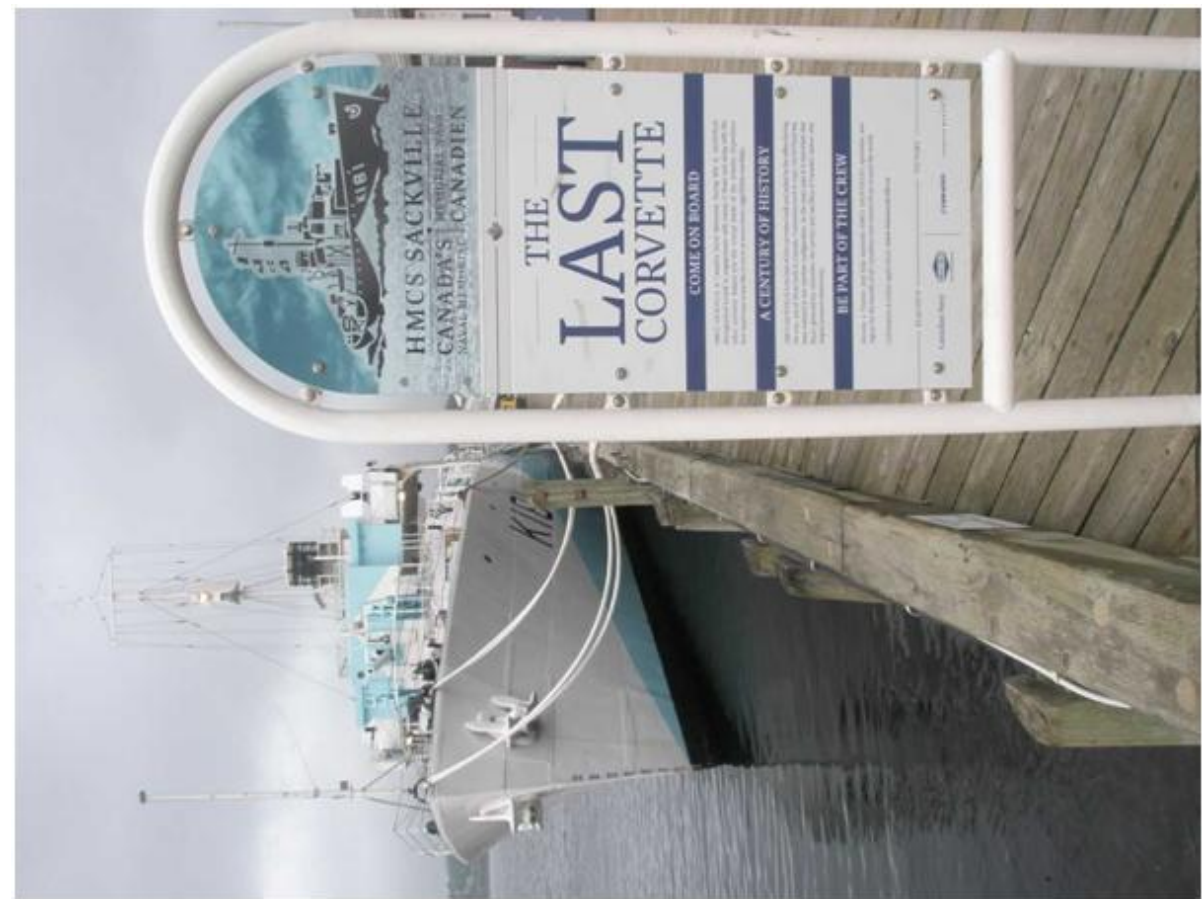

The Last Corvette (HMS Sackville), Halifax, Nova Scotia, Canada

\section{REFERENCES}

[1] R.M. Bone, The Regional Geography of Canada, $6^{\text {th }}$ edition. Vancouver: Oxford University Press Canada, 2013.

[2] C. Mayda, A Regional Geography of the United States and Canada: Toward a Sustainable Future. Rowman \& Littlefield, 2012.

[3] E. Whittcomb, E., A Short History of Nova Scotia. Ottawa: Sea to Sea Enterprises, 2009.

[4] N. Catto; S. Thompson-Graham and Vodden, K., 'Atlantic Canada',pp. 187-252, In: Tremblay, R. and Chicoine, H. (eds) The Geographies of Canada. Brussels: Peter Lang, 2013.

[5] Frost, J.D. Jr., Canada's Atlantic Gateway: An Illustrated History of the Port of Halifax. Halifax, NS: Nimbus, 2008.

[6] R. E. Gaffney, Battleground: Nova Scotia: The British, French, and First Nations at War in the Northeast 1675-1760. Xlibris, 2015. 
[7] J.M. Faragher, A Great and Noble Scene. The Tragic Story of the Expulsion of the French Acadians from Their American Homeland. New York: W.W. Norton, 2005.

[8] J. Grenier, The Far Reaches of Empire: War in Nova Scotia, 1710-1760. Norman, OK: University of Oklahoma Press, 2008.

[9] Office of Aboriginal Affairs, Nova Scotia, Canada, 'Aboriginal People in Nova Scotia', https://novascotia.ca/abor/aboriginal-people/, No date.

[10] H. Bruce, Illustrated History of Nova Scotia. Halifax, NS: Nimbus, 1997.

[11] M.A. Mitchell, Moses Perry 1714-1801: A Founding Father of Yarmouth, Nova Scotia, $3^{\text {rd }}$ ed., 2016.

[12] L.L. Kearns and N. Peters '(Re)inscribing Mi’Kmaq Presence through Public Petition, Performance and Art', pp. 75-99, In: Ashley, S.L.T (ed) Diverse Spaces. Identity, Heritage and Community in Canadian Public Culture. Newcastle upon Tyne: Cambridge Scholars Publishing, 2013.

[13] J. Boileau, Samuel Cunard: Nova Scotia's Master of the North Atlantic. James Lorimer \& Co, 2006.

[14] B. Tennyson, Merry Hell: The Story of the 25th Battalion (Nova Scotia Regiment), Canadian Expeditionary Force 1914-1919,Toronto, ON; University of Toronto Press, 2013.

[15] D. Dauphinee, Highlanders Without Kilts. United States: Kicking Pig Press, 2015.

[16] A. Hague, The Allied Convoy System 1939-1945. United States: Naval Institute Press, 2000.

[17] J. G. Armstrong and J. Griffith, The Halifax Explosion and the Royal Canadian Navy. Vancouver, BC; UBC Press, 2002.

[18] D. Flemming, Explosion in Halifax Harbour. Halifax, NS: Formac, 2004.

[19] J. Kitz and J. Payzant, December 1917: Revisiting the Halifax Explosion. Halifax, NS: Nimbus Publishing, 1989.

[20] J. A.C. Remes, Disaster Citizenship: Survivors, Solidarity, and Power in the Progressive Era. Urbana, IL: University of Illinois Press, 2016.

[21] A. Jeffers, Titanic Halifax: A Guide to Sites. Halifax, NS: Nimbus Press, 1998.

[22] N. Richardson, Halifay: The Titanic's Undertaker, The Telegraph, 11 January 2012. http://www.telegraph.co.uk/travel/destinations/north-america/canada/articles/Halifax-the-Titanicsundertaker/, No date.

[23] Maritime Museum of the Atlantic, 'Titanic: The Unsinkable ship and Halifax'. Halifax, NS: Nova Scotia Museum https://maritimemuseum.novascotia.ca/what-see-do/titanic-unsinkable-ship-and-halifax,No date.

[24] J. Dolmage, 'Grounds for Exclusion: Canada's Pier 21 and its Shadow Archive', pp. 100-121, In: Ashley, S.L.T (ed) Diverse Spaces. Identity, Heritage and Community in Canadian Public Culture. Newcastle upon Tyne: Cambridge Scholars Publishing, 2013.

[25] R.H. Whitehead, Black Loyalists. Southern Settlers of Nova Scotia's first Free Black Communities. Halifax: Nimbus, 2013.

[26] J.W. Walker Sr. (ed), The Black Loyalists: The Search for a Promised Land in Nova Scotia and Sierra Leone, 1783-1870. Toronto, ON: University of Toronto Press, 1992.

[27] Nova Scotia Museum, 'Moving on to Sierra Leone'. Halifax, NS. https://novascotia.ca/museum/blackloyalists/17751800/Events1775/sierraleone.htm, No date.

[28] P. Geoffrey, An Unsettled Conquest: The British Campaign Against the Peoples of Acadia. Philadelphia, PS: University of Pennsylvania Press, 2003.

[29] S. White, 'The True Number of Acadians' (1777), pp. 21-56, In: R. Gilles-LeBlanc. Du Grand Derangement a la Deportation: nouvelle perspectives de historiques. Moncton: Chaire d'études acadiennes, 2005.

[30] R. Rudin, Remembering and Forgetting in Acadie: A Historian's Journey through Public Memory. Toronto, ON: University of Toronto Press.

[31] S. Ross and J.A. Deveau, Acadians of Nova Scotia: Past and Present. Halifax, NS: Nimbus, 1992.

[32] L.H. Campey, After Hector: The Scottish Pioneers of Nova Scotia and Cape Breton, 1773-1852. Canada: Natural Heritage; 2nd edition, 2007.

[33] Dunn, C.W., Highland Settler. A Portrait of the Scottish Gael in Cape Breton and Eastern Nova Scotia. Breton Books, 1991

[34] N. Robinson,To the Ends of the Earth: Norman McLeod and the Highlanders' Migration to Nova Scotia and New Zealand. London: HarperCollins, 1998.

[35] S. MacKay, Flight from Famine. The Coming of the Irish to Canada. Toronto, ON: The Canadian Publisher, 1990. 
[36] Black Cultural Centre for Nova Scotia, Black Battalion. African Canadians in the First World War, Cherry Brook, N.S.: African Nova Scotian Museum. http://www.bccnsweb.com/web/our-history/black-battalionhistory/, No date.

[37] C.W. Ruck, The Black Battalion: 1916-1920: Canada's best kept military secret. Halifax, N.S.: Nimbus Publishing, 2006.

[38] Nova Scotia Archives, 'The Foreign Protestants', https://archives.novascotia.ca/genealogy/foreignprotestants, No date.

[39] Africville Museum, 'The Community of Africville' / 'About the Museum', Halifax, N.S. http://africvillemuseum.org/the-community-of-africville/; http://africvillemuseum.org/the-story/, No date.

[40] J. Nelson, The Razing of Africville: A Geography of Racism. Toronto, ON: University of Toronto Press, 2009.

Citation: Richard Kotter. Making Geographical Connections - Via Nova Scotia, Canada. International Journal of Research in Geography. vol 4, no.14, 2018, pp. 27-36. doi:http://dx.doi.org/10.20431/24548685.0401005 .

Copyright: (C) 2018Authors. This is an open-access article distributed under the terms of the Creative Commons Attribution License, which permits unrestricted use, distribution, and reproduction in any medium, provided the original author and source are credited. 